\title{
PENGARUH LIKUIDITAS DAN LEVERAGE TERHADAP PROFITABILITAS PADA PT. TELKOM INDONESIA (PERSERO), TBK YANG TERDAFTAR DI BURSA EFEK INDONESIA
}

\author{
Friska Artaria Sitanggang \\ Prodi Manajemen, Fakultas Ekonomi, Sekolah Tinggi Ilmu Ekonomi Jambi, Kota Jambi \\ e-mail: artaria888@gmail.com
}

\begin{abstract}
Abstrak
Tujuan dari penelitian ini adalah : untuk mengetahui gambaran likuiditas, leverage dan profitabilitas pada PT Telkom Indonesia (Persero), Tbk yang terdaftar di Bursa Efek Indonesia, serta untuk mengetahui pengaruh likuiditas dan leverage terhadap profitabilitas PT Telkom Indonesia (Persero), Tbk yang terdaftar di Bursa Efek Indonesia baik secara simultan maupun parsial. Teknik analisa data yang dipergunakan dalam penelitian ini adalah analisis deskriptif kualitatif dan kuantitatif. Melalui penelitian ini, akan dilakukan pengukuran tingkat leverage dengan menggunakan debt to assets ratio (DAR), tingkat likuiditas dengan menggunakan current ratio $(C R)$, dan tingkat profitabilitas dengan menggunakan Gross Profit Margin (GPM). Metode pengumpulan data dilakukan dengan dokumentasi, yakni memperoleh data dari laporan tahunan PT Telkom Indonesia (Persero), Tbk yang didapat dari Bursa Efek Indonesia periode 2015-2019 dan situs resmi milik perusahaan. Pengolahan data menggunakan Microsoft Excel 2010 dan aplikasi SPSS Versi 26.0. Hasil penelitian ini adalah : 1) Rata-rata current ratio sebesar $1.12 \mathrm{kali}$, rata-rata debt to assets ratio sebesar 0,44 kali, dan rata-rata gross profit margin sebesar 0,33 kali. 2) Hasil regresi linier berganda, yaitu $\hat{Y}=0,500+0,028 X_{1}-0,447 X_{2}$, dimana likuiditas berpengaruh positif namun tidak signifikan terhadap profitabilitas sementara leverage berpengaruh negatif dan signifikan terhadap profitabilitas pada PT Telkom Indonesia (Persero), Tbk yang terdaftar di Bursa Efek Indonesia periode 2015-2019. 3) Hasil analisis koefisien korelasi menyatakan bahwa terdapat hubungan yang kuat antara likuiditas dan leverage terhadap profitabilitas pada PT Telkom Indonesia (Persero), Tbk.
\end{abstract}

Kata kunci: Leverage, Likuiditas, dan Profitabilitas

\begin{abstract}
The purpose of this research are: to determine the representation of liquidity, leverage and profitability in PT Telkom Indonesia (Persero), Tbk which listed on the Indonesia Stock Exchange, and to determine the affect of liquidity and leverage influence in PT Telkom Indonesia (Persero), Tbk either simultaneosly or partialy. This research was done by using descriptive analysis method qualitative and quantitative. Through this research, we will measure the level of leverage using the debt to assets ratio, liquidity by using the current ratio and profitability by using Gross Profit Margin. The method of data collection is done by documentation, which is to obtain data from annual reports of PT Telkom Indonesia (Persero), Tbk obtained from the Indonesia Stock Exchange for the period 2015 - 2019 and the company's official website. Processing data using Microsoft Excel 2010 and SPSS Versi 26.0. This result of this result can be summarized as follows: 1) The average current ratio amount is 1.12 many, the average debt to assets ratio 0,44 many, and the average gross profit margin 0,33 many. 2) The test result of multiple linear regression is $\hat{\boldsymbol{Y}}=0,500+0,028 \times 1-0,447 \times 2$, mean that liquidity positive effect
\end{abstract}


not significant and leverage a negative affect but significant on profitability in PT Telkom Indonesia (Persero), Tbk. in the period 2015 - 2019 3) The result of the analysis of the correlation coefficient states that there is a strong correlation between lliquidity and leverage on profitability at PT Telkom Indonesia (Persero), Tbk.

Keywords: Leverage, Liquidity, and Profitability

\section{PENDAHULUAN}

Dalam suatu perusahaan, aktivitas keuangan perusahaan saling terintegrasi untuk mencapai tingkat profitabilitas yang menjadi target perusahaan. Aktivitas tersebut terkait penggunaan dana (keputusan investasi), memperoleh dana (kebijakan pendanaan), maupun juga pembagian laba (kebijakan deviden). Keputusan investasi mempengaruhi struktur kekayaan perusahaan yang merupakan perbandingan antara aktiva lancar dan aktiva tetap, sedangkan keputusan pendanaan dan kebijakan deviden tercermin pada sisi pasiva perusahaan. Menurut Sunyoto, Danang (2015), disebut struktur modal jika hanya memperhatikan dana yang tertanam dalam jangka waktu yang lama, dan disebut struktur modal finansial jika yang diperhatikan dana jangka panjang dan juga dana jangka pendek.

Dalam era digital saat ini kemudahan bagi publik baik investor maupun kreditor dalam mengakses informasi laporan keuangan, misalkan informasi perusahaan terkait profitabilitas perusahaan. Investor maupun calon investor sebelum menanamkan modalnya, tentu memerlukan pertimbangan yang tepat agar dana diinvestasikan pada perusahaan yang tepat. Apalagi melihat kondisi perekonomian yang tidak stabil dewasa ini, dimana keadaan cepat sekali berubah dikarenakan pengaruh banyak faktor dan situasi. Untuk itu Manajer Keuangan sebagai pihak yang mengambil keputusan krusial perusahaan baik itu dalam hal pendanaan, investasi, perlu mengambil keputusan yang bijak untuk keberlangsungan hidup perusahaan dalam menghasilkan profit maupun keuntungan.

Analisis rasio merupakan alat yang digunakan untuk membantu menganalisis laporan keuangan perusahaan sehingga dapat diketahui kekuatan dan kelemahan suatu perusahaan. Dalam penelitian ini rasio yang digunakan adalah currrent ratio (CR), debt to asset ratio (DAR), serta gross profit margin. Menurut Kasmir (2010), current ratio digunakan untuk mengukur kemampuan perusahaan membayar kewajiban jangka pendek pada saat jatuh tempo. Sedangkan untuk mengukur aspek leverage perusahaan maka diwakili dengan Debt to Asset Ratio (DAR). Leverage adalah alat untuk mengukur sampai seberapa besar perusahaan dibiayai oleh utang.

PT. Telkom Indonesia, Tbk (Persero) yang menjadi objek dalam penelitian ini adalah suatu Badan Milik Negara (BUMN) yang bergerak dalam bidang jasa Telekomunikasi dan penyedia jaringan internet terbesar di Indonesia, menyediakan sarana dan jasa layanan telekomunikasi dan informasi kepada masyarakat luas sampai kepelosok daerah di seluruh kawasan Indonesia. Berikut ini adalah Gambaran Umum current ratio, debt to assets ratio dan gross profit margin pada PT Telkom Indonesia (Persero), Tbk yang terdaftar di Bursa Efek Indonesia periode tahun 2015-2019: 
Tabel 1. Gambaran umum current ratio, debt to assets ratio dan gross profit margin Pada PT Telkom Indonesia (Persero), Tbk Periode 2015-2019

\begin{tabular}{|c|c|c|c|}
\hline Tahun & $\begin{array}{c}\text { Current Ratio } \\
(\mathbf{\%})\end{array}$ & $\begin{array}{c}\text { Debt to Assets Ratio } \\
(\mathbf{\%})\end{array}$ & $\begin{array}{c}\text { Gross Profit Margin } \\
(\mathbf{\%})\end{array}$ \\
\hline 2015 & 135,3 & 43,8 & 31,6 \\
\hline 2016 & 120 & 41,2 & 33,7 \\
\hline 2017 & 104,8 & 43,5 & 34,3 \\
\hline 2018 & 93.5 & 43,1 & 29,7 \\
\hline 2019 & 71,5 & 47 & 31,3 \\
\hline
\end{tabular}

sumber: laporan Keuangan Tahunan PT Telkom Indonesia (Persero), Tbk (data diolah),2021

Berdasarkan tabel di atas dapat dilihat bahwa profit margin pada PT. Telkom Indonesia, Tbk (Persero) dari tahun 2015 sampai 2019 berfluktuasi. Pada tahun 2015 profit margin sebesar 31,6\%, sedangkan pada tahun 2016 mengalami peningkatan menjadi $33,7 \%$ dan pada tahun 2017 kembali mengalami peningkatan menjadi 34,3\%. Pada tahun 2018 profit margin Mengalami penurunan menjadi 29,7\% dan pada tahun 2019 mengalami peningkatan Kembali menjadi 31,3\%. Variabel Gross Profit Margin tersebut menunjukkan sejauh mana kemampuan perusahaan menghasilkan profit dari kegiatan operasionalnya.

Kendati membahas rasio yang sama yakni terkait rasio profitabilitas; leverage; serta likuiditas untuk penelitian tertentu, akan tetapi objek penelitian dan periode tahun yang diteliti, serta variabel yang diterapkan juga berbeda. Bertolak dari latar belakang masalah yang telah dikemukakan, peneliti tertarik untuk mengambil judul penelitian ini.

\section{Rumusan Masalah}

a. Bagaimana gambaran likuiditas, leverage dan profitabilitas pada PT Telkom Indonesia (Persero), Tbk yang terdaftar di Bursa Efek Indonesia?

b. Bagaimana pengaruh likuiditas dan leverage terhadap profitabilitas pada PT Telkom Indonesia (Persero), Tbk yang terdaftar di Bursa Efek Indonesia baik secara parsial maupun simultan?

\section{KAJIAN PUSTAKA}

\section{Laporan Keuangan}

Laporan keuangan perusahaan dibutuhkan oleh para investor, para kreditur dan bankers, serta Pemerintah, yakni guna mengambil keputusan yang tepat. Pemerintah membutuhkan informasi laporan keuangan suatu perusahaan, misalkan untuk menentukan besarnya pajak yang dibebankan kepada perusahaan tersebut, serta berguna sebagai informasi krusial dalam perencanaan pemerintah pada Biro Pusat Statistik, Dinas Perindustrian Perdagangan dan Tenaga Kerja (Kasmir, 2010).

\section{Analisis Rasio}

Menurut Munawir (2010), rasio mendeskripsikan hubungan antara jumlah tertentu dengan jumlah yang lain, dan dapat memberikan informasi bagi penganalisa terkait baik buruknya kondisi keuangan suatu perusahaan. Dengan menerapkan Analisa ratio dapat ditentukan tingkat likuiditas, solvabilitas (leverage), keefektifan operasi, dan profitabilitas perusahaan.

\section{The Pecking Order Theory}

Hipotesis pecking order menggambarkan urutan hierarki dalam pendanaan perusahaan, yakni perusahaan lebih cenderung memilih dana internal terlebih dahulu 
(ekuitas atau modal sendiri) untuk membayar dividen dan investasi. Apabila dana eksternal dibutuhkan, perusahaan lebih menyukai utang dibandingkan dengan sumber pendanaan eksternal lainnya (Myers, 1984 dalam Rita (2009)). Teori ini hadir dikarenakan adanya informasi yang asimetris antara pihak investor dengan manajer, dalam artian manajer mendapatkan informasi yang lebih dominan dibandingkan dengan investor, sehingga dalam membuat keputusan pendanaan berdasarkan preperensi masingmasing pihak tersebut. Teori Pecking Order ini menyatakan bahwa adanya target rasio hutang yang diinginkan perusahaan, guna mencapai nilai perusahaan (Frank dan Goyal, 2005 dalam Harjito (2011)).

\section{Pengaruh Likuiditas dan Leverage Terhadap Profitabilitas}

Perusahaan yang profitable membutuhkan kucuran dana yang cukup besar untuk mendanai perusahan guna memaksimasi profit perusahaan, oleh sebab itu baik likuiditas maupun aspek leverage sangat besar pengaruhnya terhadap kebijakan investasi maupun kebijakan pendanaan perusahaan. Dimana keputusan investasi menentukan tingkat ekspansi dan kebutuhan dana perusahaan, yakni apakah dana yang telah diperoleh akan diinvestasikan pada aktiva tetap ataukah aktiva lancar, sedangkan keputusan pendanaan menentukan pemilihan sumber dana untuk membiayai investasi tersebut, yakni berasal dari hutang jangka panjang ataukah menambah proporsi penggunaan solvensi jangka pendek (Sunyoto, Danang 2015).

Likuiditas menunjukan seberapa besar kemampuan suatu perusahaan dalam melunasi solvensi jangka pendek dengan menggunakan aktiva lancar yang dimiliki perusahaan. Menurut Lyn M.Fraser (2018), solvensi jangka pendek menggambarkan sifat hutang yang paling mendesak karena harus dilunasi dalam satu siklus operasi (dalam kurun waktu satu tahun). Semakin besar rasio likuiditas (current ratio), maka menunjukkan semakin besar kemampuan perusahaan untuk memenuhi kewajiban jangka pendeknya.

Menurut Lyn M.Fraser (2018), rasio-rasio yang digunakan untuk mengukur leverage perusahaan atau menilai sejauh mana perusahaan mendanai kegiatan usahanya dengan menggunakan solvensi, merupakan rasio yang penting untuk dianalisis sebab pihak manajemen perusahaan dihadapkan pada risiko atau tingkat pengembalian (profitabilitas). Hal tersebut menunjukan pengaruh penggunaan hutang terhadap tingkat pengembalian atau keuntungan yang akan diperoleh perusahaan. Lyn M.Fraser (2018) menyatakan walaupun utang identik dengan resiko, apabila perusahaan mampu mengelolanya dengan baik maka hutang memiliki potensi untuk memperbesar keuntungan atau tingkat pengembalian yang diperoleh perusahaan, dengan asumsi bahwa pencapaian laba operasi lebih besar dan cukup untuk menutup beban bunga serta melunasi pokok hutang yang menjadi komitmen tetap bagi perusahaan.

\section{Kerangka Pemikiran}

Kerangka pemikiran dimaksudkan untuk menggambarkan paradigma penelitian sebagai jawaban atas masalah penelitian. Berikut kerangka berpikir dalam penelitian ini yang mengilustrasikan hipotesis dalam penelitian ini : 

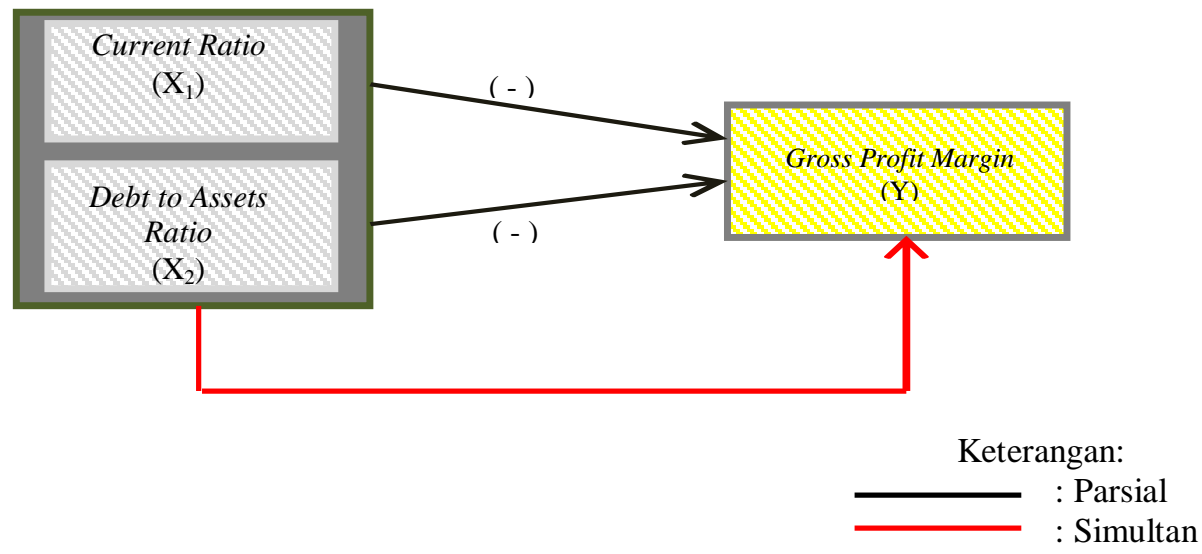

\section{Gambar 1. Kerangka Berpikir Penelitian}

\section{Hipotesis Penelitian}

Hipotesis menurut Good dan Scates dalam (Suharyadi 2016) merupakan dugaan atau referensi yang diterima sementara, yang dapat menerangkan fakta-fakta empiris yang diamati dalam proses penelitian yakni sebagai petunjuk dalam pengambilan keputusan. Berdasarkan rumusan serta tujuan penelitian, maka hipotesis penelitian ini diasumsikan sebagai berikut :

$\mathrm{H}_{1}$ : Leverage dan likuiditas secara simultan berpengaruh signifikan terhadap profitabilitas. $\mathrm{H}_{2}$ : Leverage secara parsial berpengaruh negatif signifikan terhadap profitablitas.

$\mathrm{H}_{3}$ : Likuiditas secara parsial berpengaruh negatif signifikan terhadap profitablitas.

\section{METODOLOGI PENELITIAN}

Penelitian ini dilakukan dengan menggunakan metode penelitian kuantitatif, yakni dengan menganalisis laporan keuangan PT Telkom Indonesia (Persero), Tbk. yang terdaftar di Bursa Efek Indonesia dengan periode waktu penelitian Tahun 2015-2019, sehingga digunakan data kuantitatif yang merupakan data sekunder yang dipublikasikan oleh perusahaan melalui situs resmi https://www.telkom.co.id. (Telkom, 2021). Data kuantitatif merupakan data yang dinyatakan dalam bentuk angka (Noor 2015). Pengujian hipotesis penelitian ini menggunakan penelitian asosiatif kausal, yaitu penelitian yang mencari hubungan sebab akibat antara satu variabel dengan variabel lainnya. Hubungan kasual ini bersifat sebab akibat, Adapun salah satu variabel terikat mempengaruhi variabel bebas yang lain. Desain penelitian yang digunakan dalam penelitian ini adalah penelitian kepustakaan (library research).

\section{HASIL DAN PEMBAHASAN}

\section{Analisis Statistik}

\section{a. Analisis Deskriptif Kualitatif}

Analisis deskriptif data secara kualitatif digunakan untuk memperoleh gambaran deskripsi mengenai likuiditas, leverage, serta profitabilitas pada PT Telkom Indonesia (Persero), Tbk. yang terdaftar di Bursa Efek Indonesia. Berikut adalah data current ratio (CR) pada PT Telkom Indonesia (Persero), Tbk yang terdaftar di Bursa Efek Indonesia periode 2015-2019 disajikan dalam Tabel berikut : 
Tabel 2

Gambaran Current Ratio, Debt to Asset Ratio, Gross Profit Margin pada PT Telkom Indonesia (Persero), Tbk Yang Terdaftar di Bursa Efek Indonesia Periode Tahun 2015 - 2019

(Angka dalam tabel dinyatakan dalam miliaran Rupiah)

\begin{tabular}{|c|c|c|c|c|c|c|c|c|c|c|}
\hline ahun & TW & $\begin{array}{c}\text { Aset } \\
\text { Lancar }\end{array}$ & $\begin{array}{l}\text { Utang } \\
\text { Lancar }\end{array}$ & $\begin{array}{c}\text { CR } \\
\text { (kali) }\end{array}$ & $\begin{array}{c}\text { Total } \\
\text { Utang }\end{array}$ & $\begin{array}{c}\text { Total } \\
\text { Aset }\end{array}$ & $\begin{array}{l}\text { DAR } \\
\text { (kali) }\end{array}$ & $\begin{array}{c}\text { Laba } \\
\text { Usaha }\end{array}$ & Pendapatan & $\begin{array}{l}\text { GPM } \\
\text { (kali) }\end{array}$ \\
\hline \multirow{4}{*}{2015} & $\bar{I}$ & 39.052 & 32.657 & 1.20 & 55.750 & 146.672 & 0.38 & 7448 & 23.616 & 0.32 \\
\hline & II & 42.856 & 34.380 & 1.25 & 71.785 & 154.050 & 0.47 & 15.123 & 48.840 & 0.31 \\
\hline & III & 45.586 & 33.910 & 1.34 & 71.309 & 158.394 & 0.45 & 23.992 & 75.719 & 0.32 \\
\hline & IV & 47.912 & 35.413 & 1.35 & 72.745 & 166.173 & 0.44 & 32.418 & 102.470 & 0.32 \\
\hline \multirow{4}{*}{2016} & I & 57.844 & 39.026 & 1.48 & 76.698 & 176.992 & 0.43 & 9.572 & 27.542 & 0.35 \\
\hline & II & 48.230 & 40.561 & 1.19 & 76.567 & 171.411 & 0.45 & 19.887 & 56.454 & 0.35 \\
\hline & III & 52.371 & 40.792 & 1.28 & 75.111 & 177.462 & 0.42 & 30.271 & 86.188 & 0.35 \\
\hline & IV & 47.701 & 39.762 & 1.20 & 74.067 & 179.611 & 0.41 & 39.195 & 116.333 & 0.34 \\
\hline \multirow{4}{*}{2017} & I & 54.253 & 40.687 & 1.33 & 75.133 & 187.590 & 0.40 & 12.491 & 31.022 & 0.40 \\
\hline & II & 42.012 & 39.323 & 1.07 & 75.819 & 177.843 & 0.43 & 23.786 & 64.021 & 0.37 \\
\hline & III & 51.450 & 43.193 & 1.19 & 79.937 & 190.508 & 0.42 & 35.591 & 97.003 & 0.37 \\
\hline & IV & 47.561 & 45.376 & 1.05 & 86.354 & 198.484 & 0.44 & 43.933 & 128.256 & 0.34 \\
\hline \multirow{4}{*}{2018} & $\bar{I}$ & 54.951 & 46.641 & 1.18 & 86.459 & 206.600 & 0.42 & 10.878 & 32.343 & 0.34 \\
\hline & II & 46.433 & 53.717 & 0.86 & 103.643 & 201.960 & 0.51 & 18.100 & 64.368 & 0.28 \\
\hline & III & 46.500 & 50.053 & 0.93 & 98.606 & 204.893 & 0.48 & 29.442 & 99.203 & 0.30 \\
\hline & IV & 43.268 & 46.261 & 0.94 & 88.893 & 206.196 & 0.43 & 38.845 & 130.784 & 0.30 \\
\hline \multirow{4}{*}{2019} & I & 53.871 & 51.570 & 1.04 & 93.193 & 219.111 & 0.43 & 12.029 & 34.840 & 0.35 \\
\hline & II & 48.748 & 52.587 & 0.93 & 107.354 & 215.699 & 0.50 & 22.210 & 69.345 & 0.32 \\
\hline & III & 45.127 & 53.880 & 0.84 & 98.544 & 214.990 & 0.46 & 33.454 & 102.631 & 0.33 \\
\hline & IV & 41.722 & 58.369 & 0.71 & 103.958 & 221.208 & 0.47 & 42.394 & 135.567 & 0.31 \\
\hline & & & $\begin{array}{c}\text { Rata- } \\
\text { rata }\end{array}$ & 1.12 & & $\begin{array}{c}\text { Rata- } \\
\text { rata }\end{array}$ & 0.44 & & Rata-rata & 0.33 \\
\hline & & & MAX & 1.48 & & MAX & 0.51 & & MAX & 0.40 \\
\hline & & & MIN & 0.71 & & MIN & 0.38 & & $\overline{M I N}$ & 0.28 \\
\hline
\end{tabular}

Sumber: Laporan Keuangan Triwulan PT Telkom Indonesia (Persero), Tbk (data diolah)

Berdasarkan tabel 2 di atas diketahui bahwa curent Ratio (CR) minimum perusahaan periode 2015-2019 adalah sebesar 0,71 berada pada tahun 2019 triwulan keempat. Hal ini disebabkan pada tahun 2019 triwulan keempat aset lancar perusahaan memiliki jumlah yang jauh lebih rendah dari pada solvensi jangka pendek. Curent Ratio (CR) maksimum perusahaan periode 2015-2019 adalah sebesar 1.48, yaitu pada tahun 2016 triwulan pertama. Pada saat perusahaan mencapai curent Ratio (CR) maksimum jumlah aset lancar perusahaan jauh lebih besar dari pada solvensi jangka pendek perusahaan. Rata-rata curent Ratio (CR) PT Telkom Indonesia (Persero), Tbk periode 2015-2019 yakni sebesar 1.12.

Pada Tabel 2 di atas juga dapat diketahui bahwa debt to assets ratio (DAR) minimum perusahaan periode tahun 2015-2019 adalah sebesar 0,38 berada pada tahun 2015 triwulan pertama. Kondisi tersebut menunjukkan bahwa total utang perusahaan memiliki jumlah yang relatif lebih kecil dibanding aktiva yang dimiliki perusahaan. Sedangkan debt to assets ratio (DAR) maksimum periode tahun 2015-2019 adalah sebesar 0,51, berada pada posisi tahun 2018 triwulan kedua. Rata-rata debt to assets ratio (DAR) PT Telkom Indonesia (Persero), Tbk untuk kurun waktu penelitian 2015-2019 adalah sebesar 0,44 . 
Adapun gross profit margin (GPM) yang memproyeksikan profitabilitas perusahaan, memiliki angka rasio minimum sebagaimana ditunjukkan pada tabel 2 diatas sebesar 0,28 yakni pada Tahun 2018 triwulan kedua. Sedangkan gross profit margin (GPM) maksimum berada pada Tahun 2017 triwulan pertama yakni sebesar 0,40. Semakin tinggi nilai gross profit margin (GPM), artinya kemampuan perusahaan dalam menghasilkan laba atas aset sendiri juga semakin tinggi. Hal ini berarti profitabilitas perusahaan akan dikatakan baik apabila perusahaan mampu memberikan tingkat pengembalian (keuntungan) yang tinggi, kendatipun dalam kegiatan operasionalnya perusahaan dihadapkan pada tantangan persaingan usaha serta risiko.

\section{b. Analisis Deskriptif Kuantitatif \\ Uji Asumsi Klasik \\ Uji Normalitas}

Uji normalitas dilakukan guna melihat apakah dalam model regresi variabel terikat dan variabel bebas sama-sama terdistribusi secara normal ataukah tidak. Model regresi yang baik adalah model regresi yang mempunyai data yang terdistribusi secara normal. Berdasarkan hasil yang diperoleh, dapat disimpulkan bahwa data pada penelitian ini terdistribusi secara normal. Hal ini dapat dibuktikan dari hasil uji normalitas, yakni dengan menggunakan Kolmogrov Smirnov sebagaimana yang digambarkan oleh tabel berikut, dimana nilai Asymp.Sig sebesar 0.200, yang berarti lebih besar dari 0.05 .

Tabel 3. One-Sample Kolmogorov-Smirnov Test

\begin{tabular}{llr} 
& & Unstandardized Residual \\
\hline $\mathrm{N}$ & & 20 \\
\hline Normal Parameters ${ }^{\mathrm{a}, \mathrm{b}}$ & Mean & .0000000 \\
\cline { 2 - 3 } & Std. Deviation & .02164232 \\
\hline Most Extreme Differences & Absolute & .079 \\
\cline { 2 - 3 } & Positive & .079 \\
\cline { 2 - 3 } & Negative & -.079 \\
\hline Test Statistic & & .079 \\
\hline Asymp. Sig. (2-tailed) & & $.200^{\mathrm{c}, \mathrm{d}}$ \\
\hline
\end{tabular}

sumber: data diolah dengan SPSS 26, 2021

\section{Uji Autokolerasi}

Uji autokorelasi dalam suatu model bertujuan untuk mengetahui ada tidaknya korelasi antara variabel pengganggu pada variabel tertentu dengan variabel sebelumnya. untuk data time series autokorelasi sering terjadi, tapi untuk data yang sampelnya crossection jarang terjadi karena variabel pengganggu satu berbeda dengan yang lain. (Ukhriyawati dan Putri 2016). Berdasarkan hasil uji autokolerasi, dapat dilihat bahwa nilai Durbin-Watson sebesar 0.944, sehingga artinya dalam model penelitian ini tidak terjadi autokorelasi, dibuktikan dengan nilai Durbin Watson sebesar $0.944>0.05$, sehingga dapat disimpulkan bahwa dalam penelitian ini tidak terjadi autokorelasi. 
Tabel 4. Hasil Uji Autokolerasi

\begin{tabular}{|c|c|c|c|c|c|c|c|c|c|c|}
\hline \multicolumn{11}{|c|}{ Model Summary } \\
\hline & & & & Std. Error & & Chang & Statis & & & \\
\hline $\begin{array}{l}\text { Mo } \\
\text { del }\end{array}$ & $\mathrm{R}$ & $\begin{array}{c}\mathrm{R} \\
\text { Square }\end{array}$ & $\begin{array}{l}\text { Adjusted } \\
\text { R Square }\end{array}$ & $\begin{array}{c}\text { of the } \\
\text { Estimate }\end{array}$ & $\begin{array}{l}\text { R Square } \\
\text { Change }\end{array}$ & $\begin{array}{c}\mathrm{F} \\
\text { Change }\end{array}$ & df1 & $\mathrm{df} 2$ & $\begin{array}{c}\text { Sig. F } \\
\text { Change }\end{array}$ & $\begin{array}{l}\text { Durbin- } \\
\text { Watson }\end{array}$ \\
\hline 1 & $.645^{\mathrm{a}}$ & .417 & .348 & .02288 & .417 & 6.070 & 2 & 17 & .010 & .944 \\
\hline
\end{tabular}

Sumber: data diolah dengan SPSS 26, 2021

Uji Multikolonearitas

Tabel 5. Hasil Uji Multikolonearitas Coefficients $^{\mathrm{a}}$

\begin{tabular}{ll|r|r} 
& & \multicolumn{2}{c}{ Collinearity Statistics } \\
Model & & Tolerance & \multicolumn{1}{c}{ VIF } \\
\hline 1 & & & \\
\cline { 2 - 4 } & (Constant) & .685 & 1.460 \\
\hline & current ratio & .685 & 1.460 \\
\hline
\end{tabular}

Sumber: data diolah dengan SPSS 26, 2021

Berdasarkan hasil uji multikolonearitas diatas, dapat disimpulkan bahwa tidak terjadi multikolonearitas pada data yang dipergunakan dalam penelitian ini. Pernyataan tersebut didasari oleh hasil uji diatas, dimana diketahui:

a. Nilai Tolerance variabel current ratio dan debt to asset ratio yaitu $0.685>0.10$

b. Nilai VIF variabel current ratio dan debt to asset ratio yaitu $1.460<10.00$

\section{Uji Heteroskedastisitas}

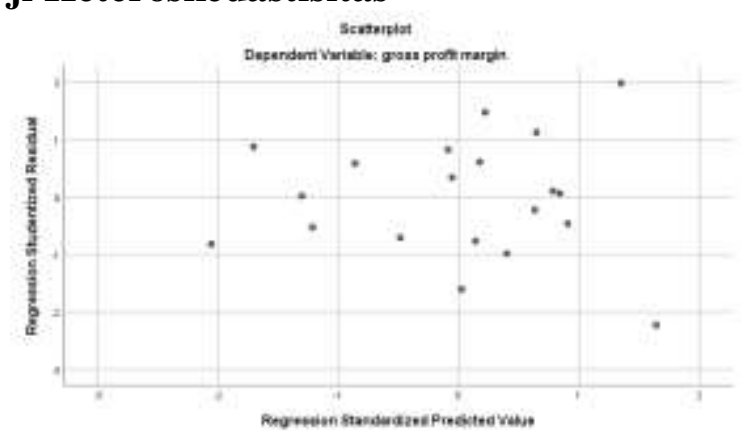

\section{Gambar 2. Hasil Uji Heteroskedastisitas}

sumber: data diolah dengan SPSS 26, 2021

Berdasarkan gambar diatas, dapat disimpulkan bahwa tidak terjadi heteroskedastisitas pada data yang dipergunakan dalam penelitian ini. Hal ini dapat dibuktikan dari gambar terlihat bahwa titik-titik menyebar secara acak dan tidak membentuk sebuah pola tertentu, serta tersebar baik diatas maupun dibawah angka nol pada sumbu Y. 


\section{Tabel 6. Analisis Regresi Linier Berganda}

\begin{tabular}{|c|c|c|c|c|}
\hline \multirow{2}{*}{\multicolumn{2}{|c|}{ Model }} & \multicolumn{2}{|c|}{ Unstandardized Coefficients } & \multirow{2}{*}{$\begin{array}{l}\text { Standardized } \\
\text { Coefficients } \\
\text { Beta }\end{array}$} \\
\hline & & $\mathrm{B}$ & Std. Error & \\
\hline \multirow[t]{3}{*}{1} & (Constant) & .500 & .110 & \\
\hline & Current Ratio & .028 & .031 & .197 \\
\hline & Debt to Asset Ratio & -.447 & .195 & -.514 \\
\hline
\end{tabular}

a. Dependent Variable: Gross Profit Margin

sumber: data diolah dengan SPSS 26, 2021

Berdasarkan tabel diatas, model persamaan regresi yang diperoleh adalah:

$$
\hat{\mathbf{Y}}=\mathbf{0 , 5 0 0}+\mathbf{0 , 0 2 8} \mathrm{X}_{1}-\mathbf{0 , 4 4 7} \mathrm{X}_{\mathbf{2}}
$$

Berdasarkan hasil persamaan regresi di atas, maka dapat dijelaskan sebagai berikut :

a. Likuiditas berpengaruh dengan arah hubungan positif terhadap profitabilitas pada PT Telkom Indonesia (Persero) Tbk yang Terdaftar di Bursa Efek Indonesia periode 2015- 2019.

b. sementara leverage berpengaruh dengan arah hubungan negatif terhadap profitabilitas pada PT Telkom Indonesia (Persero) Tbk yang Terdaftar di Bursa Efek Indonesia periode 2015- 2019.

\section{Koefesien Korelasi \& Koefisien Determinasi}

Dari tabel 4 diatas dapat dilihat nilai koefisien korelasi (r) adalah 0.645 berada pada interval koefisien 0,6 s.d $<0,8$, hal ini menunjukkan bahwa hubungan Likuiditas (CR) dan Leverage (DAR) dengan variabel dependen profitabilitas (GPM) hubungannya besar atau kuat pada PT Telkom Indonesia, Tbk (Persero) yang terdaftar di Bursa Efek Indonesia. Selanjutnya koefisien determinasi (R) menunjukkan angka 0,417 atau $41.7 \%$. Berarti bahwa Current Ratio dan Debt to Assets Ratio mampu menjelaskan variabel Gross Profit Margin sebesar 41.7\%, sedangkan sisanya 58,3\% dapat dijelaskan oleh variabel lain yang tidak dibahas dalam penelitian ini.

\section{Uji Hipotesis}

Hipotesis yang diuji dalam penelitian ini adalah uji simultan (Uji F) dan uji parsial (Uji t), sebagai berikut :

\section{Uji Simultan (Uji F)}

Uji $F$ menunjukkan apakah semua variabel idependen yang dimasukkan dalam model regresi mempunyai pengaruh secara bersama-sama terhadap variabel dependen. Pada saat melakukan uji F Hitung, sebenarnya peneliti telah melakukan Uji Goodness of Fit, yakni untuk mengetahui layak tidaknya model dalam penelitian ini.

Hasil uji F hitung dalam penelitian ini, disajikan pada Tabel sebagai berikut : 
Tabel 7. Uji Kelayakan Model (uji goodness of fit)

\begin{tabular}{|c|c|c|c|c|c|c|}
\hline \multicolumn{7}{|c|}{ ANOVA $^{a}$} \\
\hline \multicolumn{2}{|c|}{ Model } & Sum of Squares & df & Mean Square & $\mathrm{F}$ & Sig. \\
\hline \multirow[t]{3}{*}{1} & Regression & .006 & 2 & .003 & 6.070 & $.010^{\mathrm{b}}$ \\
\hline & Residual & .009 & 17 & .001 & & \\
\hline & Total & .015 & 19 & & & \\
\hline
\end{tabular}

a. Dependent Variable: Gross Profit Margin

b. Predictors: (Constant), Debt to Asset Ratio, Current Ratio

Sumber: data diolah dengan SPSS 26, 2021

Berdasarkan tabel di atas, hasil uji $\mathrm{F}_{\text {hitung }}$ adalah 6.07 dan dengan menggunakan tabel $\mathrm{F}$ diperoleh nilai $\mathrm{F}_{\text {tabel }}$ sebesar 3,59. Hal ini menunjukkan bahwa $F_{\text {hitung }}(6.07)>$ $\mathrm{F}_{\text {tabel }}(3,59)$ dan tingkat signifikansi $0.010<0,05$ sehingga $\mathrm{H} 1$ diterima artinya likuiditas dan leverage berpengaruh signifikan terhadap profitabilitas pada PT Telkom, Tbk. yang terdaftar di Bursa Efek Indonesia secara simultan. Nilai signifikasi yang lebih kecil dari $5 \%$ berdasarkan hasil uji goodness of fit diatas, menyatakan bahwa model layak digunakan dalam penelitian ini, sehingga pengujian hipotesis dapat dilakukan. Uji keselarasan (uji goodness of fit) digunakan untuk menguji ketepatan frekuensi yang teramati, yakni apakah sudah sesuai dengan frekuensi yang diharapkan (Suharyadi, 2016).

\section{Uji Parsial (Uji t)}

Uji t dilakukan untuk menguji signifikan tidaknya pengaruh antara variabel independen terhadap variabel dependen dengan asumsi bahwa variabel lainnya dianggap konstan. Hasil perhitungan dengan bantuan SPSS versi 26.0, dimana nilai t hitung dapat dilihat pada tabel berikut:

\section{Tabel 8. Hasil Uji t \\ Coefficients $^{\mathrm{a}}$}

\begin{tabular}{llr|r} 
& & & \\
Model & & \multicolumn{1}{c|}{ Sig. } \\
\hline $1 \quad$ (Constant) & 4.554 & .000 \\
\cline { 2 - 4 } & Current Ratio & .882 & .390 \\
\cline { 2 - 4 } & Debt to Asset Ratio & -2.295 & .035 \\
\hline a. Dependent Variable: GPM & &
\end{tabular}

Sumber: data diolah dengan SPSS 26, 2021

Berdasarkan hasil uji t yang disajikan pada tabel di atas, maka diketahui pengaruh masing-masing variabel independen terhadap variabel dependen sebagai berikut:

\section{a. Pengaruh Likuiditas (CR) terhadap Profitabilitas}

Pada tabel diatas, variabel curent ratio (CR) mempunyai $t_{\text {hitung }}$ yakni 0,882 dengan $\mathrm{t}_{\text {tabel }}=2,10982$. Jadi $\mathrm{t}_{\text {hitung }}(0,882)<\mathrm{t}_{\text {tabel }}(2,10982)$ dapat disimpulkan bahwa curent ratio (CR) memiliki kontribusi terhadap variabel Y (GPM). Nilai sig untuk CR 0,390 atau nilai 
sig lebih besar dari nilai signifikansi 0,05 atau nilai $0,390>0,05$, maka $\mathrm{H}_{3}$ ditolak. Artinya bahwa likuiditas berpengaruh tidak signifikan terhadap profitabilitas pada PT Telkom Indonesia (Persero) Tbk yang terdaftar di Bursa Efek Indonesia.

\section{b. Pengaruh Leverage (DAR) terhadap Profitabilitas}

Pada tabel diatas juga menunjukkan bahwa debt to assets ratio mempunyai $t_{\text {hitung }}$ yakni -2.295 dengan $t_{\text {tabel }}=2,10982$. Jadi, $t_{\text {hitung }}(-2.295)>t_{\text {tabel }}(2,10982)$ artinya bahwa variabel $\mathrm{X}_{2}$ (DAR) memiliki kontribusi terhadap $\mathrm{Y}$ (GPM). Nilai sig untuk DAR 0,035 lebih kecil dari nilai signifikansi 0,05 atau nilai $0,035<0,05$, maka H2 diterima. Dengan demikian dapat disimpulkan bahwa leverage berpengaruh signifikan terhadap profitabilitas pada PT Telkom Indonesia (Persero), Tbk yang terdaftar di Bursa Efek Indonesia.

\section{Evaluasi Hasil}

a. Evaluasi Likuiditas pada PT Telkom Indonesia (Persero), Tbk yang Terdaftar di Bursa Efek Indonesia

Angka Current ratio pada PT Telkom Indonesia (Persero), Tbk periode 2015-2019 berfluktuasi, dengan rata-rata rasio lancar pertahun sebesar 1.12 kali. Kondisi ini dapat dilihat pada tahun 2019 triwulan keempat dengan current ratio minimum sebesar 0.71 yang berarti dibawah rata-rata, hasil current ratio ini disebabkan oleh meningkatnya jumlah aktiva lancar perusahaan yang dapat dilihat dari piutang usaha, tagihan restitusi pajak, kas dan setara kas. Sedangkan penurunan terjadi pada aspek likuiditas yakni aset keuangan lancar lainnya, piutang lain-lain, persediaan, aset tersedia untuk dijual, pajak dibayar dimuka, dan aset lancar lainnya, sehingga kenaikan pada aktiva lancar dikatakan tidak signifikan mempengaruhi profitabilitas perusahaan yang diproksi oleh gross profit margin.

Adapun secara parsial dari hasil analisis statistik, diketahui bahwa likuiditas berpengaruh positif namun tidak signifikan terhadap profitabilitas PT Telkom Indonesia (Persero), Tbk khususnya pada periode tahun 2015-2019, Hasil penelitian ini berbeda dengan hasil penelitian yang telah dilakukan oleh Arifin, et.al (2019); Tanzil (2017); Soepardi et al. (2014); Adindaningtyas, Puri (2017) yang menyatakan bahwa adanya pengaruh negatif dan signifikan rasio likuiditas (CR) terhadap profitabilitas yang dimiliki perusahaan, dengan kata lain bahwa apabila likuiditas semakin besar maka akan diikuti oleh turunnya profitabilitas. Arifin, et.al (2019) berasumsi bahwa kondisi tersebut terjadi dikarenakan masih adanya dana-dana yang menganggur yang sebenarnya dapat digunakan untuk berinvestasi guna memaksimasi profit perusahaan.

Hasil penelitian ini sejalan dengan penelitian yang dilakukan oleh Silitonga, et.al, (2017); Irawati (2020); Islami dan Isynuwardhana (2019); Saragih et al. (2018); Ukhriyawati dan Putri (2016); Ratnasari dan Budiyanto (2016); Widjaja (2019); Lovi Anggarsari (2018) dimana likuiditas berpengaruh tidak signifikan terhadap profitabilitas. Saragih et al. (2018) menyatakan rasio leverage yang tinggi harus dihindari, sebab berpengaruh pada eksistensi perusahaan di masa yang akan datang. Likuiditas yang tinggi tidak selalu menguntungkan hal ini dapat menimbulkan dana-dana yang menganggur, yang seharusnya dapat dialokasikan perusahaan kedalam bentuk investasi yang menguntungkan untuk menjaga sustainable perusahaan (Fitri dan Supriyanto (2016) dalam Lovi Anggarsari, (2018)). 


\section{b. Evaluasi Leverage pada PT Telkom Indonesia (Persero), Tbk yang Terdaftar di Bursa Efek Indonesia}

Angka Debt to Assets Ratio pada PT Telkom Indonesia (Persero), Tbk cenderung berfluktuasi dalam periode 2015-2019 dengan hasil rata-rata akhir 0,44. Kondisi yang berfluktuasi pada total debt to assets ratio perusahaan, dikarenakan komposisi total utang PT Telkom Indonesia (Persero), Tbk yang berubah selama periode penelitian terhadap total aktiva yang dimiliki perusahaan. Debt to Assets Ratio pada tahun 2015-2019 memiliki nilai minimum 0.38 yakni pada tahun 2015 triwulan pertama, menggambarkan nilai total asset yang lebih besar dibandingkan total hutang yang dimiliki perusahaan. Nilai maksimum DAR diangka 0,51 kali atau $51 \%$ yang juga masih menunjukkan perbandingan yang lebih besar total aktiva terhadap total hutang, kondisi tersebut memberi gambaran bahwa PT Telkom Indonesia (Persero), Tbk. mampu mengelola solvensi jangka pendek dan jangka panjang yang dimiliki untuk meningkatkan jumlah aktiva perusahaan. Berdasarkan hasil analisis statistik diketahui bahwa leverage perusahaan yang diwakili dengan Debt to Asset Ratio berpengaruh negatif signifikan terhadap profitabilitas perusahaan, artinya peningkatan solvensi akan menurunkan perolehan laba perusahaan. Hasil yang diperoleh dari penelitian ini tidak sejalan dengan hasil penelitian dari Arifin,et.al (2019); Saragih et al. (2018); Soepardi et al. (2014); Adindaningtyas, Puri (2017); Ukhriyawati dan Putri (2016); Lovi Anggarsari (2018) yang menyatakan bahwa variabel leverage berpengaruh tidak signifikan terhadap variabel profitabilitas dalam perusahaan yang diteliti.

Hasil yang diperoleh dalam penelitian ini sejalan dengan implementasi Teori Pecking Order. Teori tersebut mengasumsikan bahwa adanya arah hubungan negatif atau terbalik yakni antara rasio leverage terhadap tingkat profitabilitas perusahaan (Harjito 2011). Semakin besar penggunaan utang dalam Teori Pecking Order, menunjukkan bahwa semakin besar biaya yang harus ditanggung perusahaan untuk memenuhi kewajiban yang dimilikinya sehingga dapat menurunkan profitabilitas yang dimiliki perusahaan (Arifin, et.al, 2019). Penelitian ini juga sejalan dengan hasil riset yang dilakukan oleh Silitonga, et.al (2017); Irawati (2020); Tanzil (2017); Islami dan Isynuwardhana (2019); Ratnasari dan Budiyanto (2016); Widjaja (2019), yang menyatakan bahwa leverage berpengaruh signifikan terhadap profitabilitas dengan arah hubungan negatif.

\section{c. Evaluasi Profitabilitas pada PT Telkom Indonesia (Persero), Tbk yang Terdaftar di Bursa Efek Indonesia}

Gross Profit Margin Ratio pada PT Telkom Indonesia (Persero), Tbk yang terdaftar di Bursa Efek Indonesia berfluktuasi selama periode penelitian 2015-2019. Nilai rata-rata akhir Gross Profit Margin Ratio sebesar 0,33, nilai maksimum gross profit margin (GPM) terjadi pada tahun 2017 triwulan pertama yakni sebesar 0.40 atau 40\%, sedangkan nilai gross profit margin (GPM) minimum terjadi pada tahun 2018 triwulan kedua dengan angka rasio 0.28 atau 28\%. Angka ratio yang diperoleh oleh perusahaan dalam kurun waktu penelitian tersebut, menggambarkan kemampuan perusahaan dalam mengelola dana atau aktiva yang dimiliki dalam upaya memaksimumkan profit. PT Telkom Indonesia (Persero), Tbk mampu beradaptasi dengan transformasi zaman yang saat ini berada dalam era digitalisasi sebagai upaya dalam menjaga eksistensi perusahaan, dimana sistem pelayanan perusahaan ini merambah ke dunia digitalisasi penyediaan jaringan internet yang dulunya fokus kepada jasa telekomunikasi khususnya penggunaan telepon rumah dan telepon genggam. 


\section{d. Evaluasi Pengaruh Likuiditas dan Leverage Terhadap Profitabilitas pada PT Telkom Indonesia (Persero), Tbk yang Terdaftar di Bursa Efek Indonesia}

Berdasarkan hasil pengujian secara simultan yakni melalui Uji F, diperoleh bahwa likuiditas yang diproyeksikan oleh current ratio dan leverage yang diproyeksikan oleh debt to asset ratio, berpengaruh signifikan terhadap profitabilitas yang diproksi oleh gross profit margin pada PT Telkom Indonesia (Persero) Tbk yang terdaftar di Bursa Efek Indonesia, yakni dengan nilai signifikansi $0.010<0.05$. Berdasarkan hasil analisis diketahui bahwa nilai $F$ hitung $(6.07)>F_{\text {tabel }}(3,59)$, sehingga dapat disimpulkan bahwa kemampuan likuiditas (CR) dan tingkat kemampuan leverage (DAR) pada PT Telkom Indonesia (persero) Tbk ini mempengaruhi kondisi profitabilitas perusahaan. Hasil penelitian ini tidak sejalan dengan hasil riset dari Silitonga, et.al (2017); Saragih et al. (2018), yang menyatakan bahwa secara bersama-sama rasio likuiditas dan rasio leverage berpengaruh tidak signifikan terhadap profitabilitas. Namun hasil penelitian ini sejalan dengan hasil riset dari Irawati (2020); Tanzil (2017); Islami dan Isynuwardhana (2019); Soepardi et al. (2014); Adindaningtyas, Puri (2017); Ukhriyawati dan Putri (2016); Ratnasari dan Budiyanto (2016), yang menyatakan secara simultan likuiditas dan solvabilitas berpengaruh terhadap profitabilitas (keuntungan) perusahaan.

\section{SIMPULAN DAN SARAN}

\section{Simpulan}

1. Hasil pengujian uji t (secara parsial) disimpulkan bahwa likuiditas berpengaruh positif tidak signifikan terhadap profitabilitas, dengan arah hubungan yang searah yakni pada PT Telkom Indonesia (Persero), Tbk yang terdaftar di Bursa Efek Indonesia selama kurun waktu penelitian Tahun 2015-2019. Hal ini ditunjukan untuk Current Ratio $\mathrm{t}_{\text {hitung }}(0,882)<\mathrm{t}_{\text {tabel }}(2,10982)$ atau nilai sig $0.390>0,05$, sehingga hipotesis 3 ditolak.

2. Untuk variabel leverage berpengaruh negatif signifikan terhadap profitabilitas pada PT Telkom Indonesia (Persero), Tbk yang terdaftar di Bursa Efek Indonesia. Hal ditunjukan dengan $t_{\text {hitung }}(-2,295)>t_{\text {tabel }}(2,10982)$ atau nilai sig $0,035<0,05$, sehingga Hipotesis 2 diterima.

3. Secara simultan (Bersama-sama) variabel likuiditas (CR) dan variabel leverage (DAR) berpengaruh terhadap profitabilitas (GPM) pada PT Telkom Indonesia (Persero), Tbk, hal tersebut ditunjukkan oleh Fhitung $(6.07)>F_{\text {tabel }}(3,59)$ dengan tingkat signifikansi $0.010<0.05$, sehingga hipotesis 1 diterima.

\section{Saran}

Perusahaan tidak perlu khawatir dalam hal mengoptimalkan penggunaan utang jangka pendek selagi masih dalam taraf kewajaran, karena dari hasil penelitian likuiditas yang diproksi oleh variabel current ratio berpengaruh namun tidak signifikan terhadap profitabilitas PT Telkom Indonesia (Persero) Tbk yang diproksi oleh variabel gross profit margin. Seyogyanya penambahan utang jangka pendek selaras dengan penggunaan dana secara efektif, untuk meningkatkan jumlah aktiva ataupun laba (profit) perusahaan.

Dari perspektif leverage, perusahaan perlu mempertimbangkan proporsi utang jangka panjang yang dimiliki oleh PT Telkom Indonesia (Persero) Tbk yang diproksi oleh variabel debt to asset ratio (DAR) dalam hal pendanaan perusahaannya, dikarenakan hasil penelitian menunjukkan pengaruh yang signifikan variabel DAR terhadap tingkat profitabilitas yang dicapai oleh perusahaan dengan arah hubungan negatif. Untuk mengoptimalkan utang jangka panjang penambahan utang diperkenankan selagi masih 
dalam taraf kewajaran, serta mampu menghasilkan profit yang mampu meningkatkan kemampuan leverage perusahaan yakni dalam menutup beban bunga atau kewajiban pada saat jatuh tempo.

Bagi penelitian selanjutnya, peneliti dapat menggunakan variabel yang sama dengan variabel yang digunakan dalam penelitian ini, ataupun dengan menerapkan variabel yang berbeda, dengan objek serta periode waktu penelitian yang berbeda, maupun dengan menerapkan scope yang lebih luas yakni menggunakan data industri.

\section{DAFTAR PUSTAKA}

Adindaningtyas, Puri, Triyonowati. 2017. "Pengaruh Leverage Dan Likuiditas Terhadap Profitabilitas Pada PT Semen Gresik (Persero) Tbk." Jurnal Ilmu dan Riset Manajemen 6(12): 2461-0593.

Arifin, Dedy Samsul, Buyung Sarita, Riski Amalia Madi. 2019. "Pengaruh Likuiditas, Leverage, Ukuran Perusahaan Dan Pertumbuhan Penjualan Terhadap Profitabilitas (Studi Pada Perusahaan Property dan Real Estate Yang Terdaftar di Bursa Efek Indonesia Tahun 2013-2017)." Jurnal Manajemen Dan Kewirausahaan Halu Oleo University 11(2). http://ojs.uho.ac.id/index.php/manajemen/index.

Harjito, D Agus. 2011. "Teori Pecking Order dan Trade-Off dalam Analisis Struktur Modal di Bursa Efek Indonesia.” Jurnal Siasat Bisnis 15(2): 187-96.

Horne, James C. Van and Wachowicz. 2012. Prinsip-prinsip Manajemen Keuangan. Jakarta: Salemba Empat.

Irawati, Fitria Ningsih. 2020. "Pengaruh Likuiditas dan Solvabilitas Terhadap Rentabilitas Ekonomis pada Koperasi Sawit Usaha Manunggal Desa Seresam Kecamatan Seberida Kabupaten Indragiri Hulu.” Jurnal Manajemen dan Sains 5(April): 48-51.

Islami, Mauludy Arfan, dan Deannes Isynuwardhana. 2019. "Pengaruh Leverage dan Likuiditas Terhadap Profitabilitas (Studi Pada Perusahaan Manufaktur Sub Sektor Tekstil dan Garment yang Terdaftar di Bursa Efek Indonesia Periode 2014 - 2018 ) The Effect Of Leverage and Liquidity On Profitability." e-Proceeding of Management 6(2): 3381-90.

Kasmir. 2010. Analisis Laporan Keuangan. Jakarta: Rajawali Pers.

Lovi Anggarsari, Tony Seno Aji. 2018. "Pengaruh Ukuran Perusahaan, Leverage, Likuiditas, Perputaran Modal Kerja Dan Pertumbuhan Penjualan Terhadap Profitabilitas (Sektor Industri Barang Dan Konsumsi Yang Terdaftar Di Bursa Efek Indonesia Periode 2013-2016)." Jurnal Ilmu Manajemen (JIM) 6(4): 542-49.

Lyn M.Fraser, Aileen Ormiston. 2018. Memahami Laporan Keuangan. Jakarta: Indeks.

Munawir. 2010. Analisis Laporan Keuangan. Yogyakarta: Liberty.

Noor, Juliansyah. 2015. Analisis Data Penelitian Ekonomi dan Manajemen. Jakarta: Grasindo.

Ratnasari, Linda, dan Budiyanto. 2016. "Pengaruh Leverage, Likuiditas, Ukuran Perusahaan terhadap Profitabilitas pada perusahaan otomotif di BEI." Ilmu dan Riset Manajemen 5(6): 1-15.

Rita, Mutamimah. 2009. "Keputusan Pendanaan: Pendekatan Trade-Off Theory Dan Pecking Order Theory." EKOBIS: 241-49.

Saragih, Murni Sari Dewi, Liper Siregar, Efendi Efendi, dan Ady Inrawan. 2018. "Pengaruh Likuiditas Dan Leverage Terhadap Profitabilitas Pada Pt Hanjaya Mandala Sampoerna, Tbk Yang Terdaftar Di Bursa Efek Indonesia." SULTANIST: Jurnal Manajemen dan Keuangan 4(2): 59-65. 
Silitonga, Hery Pandapotan, Parman Tarigan, dan Ady Inrawan. 2017. "Pengaruh Likuiditas Dan Leverage Terhadap Profitabilitas Pada PT Japfa Comfeed Indonesia, Tbk . Yang Terdaftar di Bursa Efek Indonesia.” Jurnal Financial 3(1): 1-9.

Soepardi, Eddy Mulyadi, Sigit Edy Surono, Eka Ponpon Sejati, dan Jungjungan. 2014. "Analisis Likuiditas Dan Leverage Terhadap Profitabilitas Perusahaan Yang Terdaftar Di Bursa Efek Indonesia." Jurnal Ilmiah Magister Manajemen MAGMA 1(1): 2-10. https://journal.unpak.ac.id/index.php/magma/article/view/307.

Sugiyono. 2013. Metode Penelitian Kuantitatif Kualitatif dan R\&D. Alfabeta.Bandung.

Suharyadi, Purwanto. 2016. Statistika: Untuk Ekonomi dan Keuangan Modern. Jakarta: Salemba Empat.

Sunyoto, Danang, Fathonah Eka Susanti. 2015. Manajemen Keuangan Untuk Perusahaan. Pertama. PT Buku Seru.Jakarta.

Tanzil, Cindya Tria. 2017. "Pengaruh Likuiditas Dan Leverage Terhadap Profitabilitas Pada Perusahaan Sub Sektor Industri Barang Konsumsi Yang Terdaftar di Bursa Efek Indonesia." Jurnal Sultanist 6(2): 10-17.

Telkom, Indonesia (Persero) Tbk. (diakses 16 Februari 2021). "Laporan Keuangan PT Telkom Indonesia (Persero), Tbk." diperoleh dari https://www.telkom.co.id/sites

Ukhriyawati, Catur F, dan Raja Wulandari Putri. 2016. "Pengaruh Likuiditas, Leverage dan Profitabilitas terhadap Nilai Perusahaan pada Perusahaan Telekomunikasi yang Terdaftar di Bursa Efek Indonesia Tahun 2012-2014.” Jurnal Bening 3(1): 52-73.

Widjaja, Ellysa Fransisca dan Indra. 2019. "Pengaruh Leverage, Pertumbuhan Penjualan Dan Ukuran Perusahaan Terhadap Profitabilitas." Jurnal Manajerial dan Kewirausahaan 1: 199-206. 